\title{
Measurement Of Customer Satisfaction Index (Csi) At Bank Tabungan Negara Corporation (Ltd),Surabaya Office Branchas An Effort To Improve Service
}

\author{
Didik Mujayadi ${ }^{1}$ \\ \{didik.mujayadi92@gmail.com\} \\ Postgraduate, Engineering Management Institut Teknologi Sepuluh Nopember, Surabaya
}

\begin{abstract}
Companies in the financial industry continue to increase in number along with development of the city of Surabaya. This results in the intensification of competition to gain more and more customers or at least to maintain the number of loyal customers. Likewise, Bank Tabungan Negara Corporation (Ltd) seeks to realize this goal. This is thedriving force for Bank Tabungan Negara Corporation, Surabaya Branch Office in order to further enhance its ability to have an advantage over existing banking competitors, aiming to maintain customer satisfaction which plays a very crucial role in having a competitive edge in the financial field.
\end{abstract}

Keywords: customer satisfaction, SERVQUAL, structural equation model partial least square (SEM-PLS).

\section{Introduction}

Quality involves adynamic statebetween products, services, people, processes, and environments that meet or exceed expectations (Tjiptono, 2007). Another definition of quality is the degree achieved by the related features in order to fulfill the criteria (Lupiyoadi and Hamdani, 2006). Service quality is a level of advantagethat is expected and the control over that advantagein fulfilling customers'requests. There are two factors affecting service quality, namely the customers' perception towards the actual services they receive (perceived service) and the ideal services that are expected / desired (Expected Service). Clients' satisfaction is determined by the quality of service, in this case the quality of service consists of reliability, guarantee, facility, response, and empathy. What is necessary to support the company in analyzing the needs of customers is by knowing the level of customer satisfaction. Customer satisfaction is one keythat becomes a parameter of the success or failure of a company in marketing its products. Although customer satisfaction is abstract, it can be quantified. Measuring customer satisfaction is crucial to a company, because measuring customer satisfaction can reveal whether there is discrepancy between the quality of service expected by the customer and the service quality perceived/received by the customer of a bank. Customer satisfaction is the customers' response to the inadequacy between the level of prior interest and actual performance that is felt after use (Hartono, 2008). According to Supranto (2002) there are three levels of customer satisfaction, namely very satisfied customers, satisfied customers, and dissatisfied customers. Customers are very satisfied if perceived service is beyond the expected service. Customers are satisfied if the perceived service is the same as the 
expected service. Customers are not satisfied if the perceived service is not as good as the expected service. Previous research on SERVQUAL was conducted byKhafafa (2013) on customer satisfaction in Libyan commercial banks, using structural equation models (SEM) with modified dimensions of the SERVQUAL model as follows.

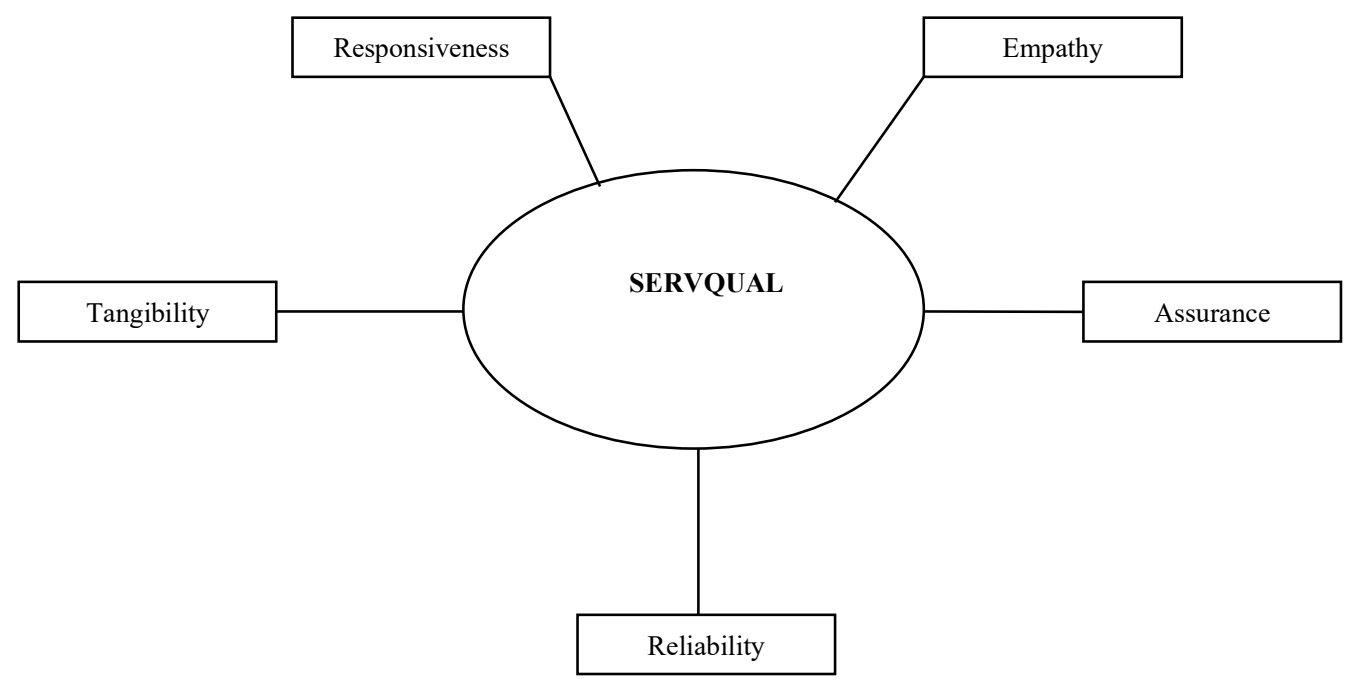

In the current era,small and large scale service companies are emerging, competing for the broadest portion of the market. With the existing increasingly fierce competition, companies must have the right strategy to achieve their objectives. Considering that the availability of customers is an important factor in achieving goals, companies arebecoming increasingly aware of the need for an analysis of the role of customers. In its efforts to serve customers as market segment, a company must understand the desires and needs of customers in order to provide optimal customers'satisfaction.

\section{Method}

This study utilizes interview and questionnaire methods. The questions in the questionnaire are closed questions designed based on the Likert scale. According to Umar (2005), this scale is used to measure attitudes, opinions, and perceptions of a person or group of people concerning social phenomena. The data obtained in this study are subject datain the form of opinions, attitudes, experiences or characteristics of a person or group that is the subject of research or respondents (Indrianto and Supomo, 1999) obtained directly from customers of Bank Tabungan Negara Corporation (Ltd) Surabaya BranchOffice. The population is the total number of respondents from the unit of analysis whose characteristics are assumed (Masri, 1995). Another view of population is a generalized area consisting of objects/subjects that have certain qualities and characteristics set by the researcher to investigate and then draw conclusions (Sugiono, 1999). The population in this study is the customers of Bank Tabungan Negara Corporation (Ltd) Surabaya Branch Office. Population and population sampling, namely a group of people, eventsor everything that has certain characteristics. For this study, the population is the customers of Bank Tabungan Negara 
Corporation (Ltd) Surabaya Branch Office. Sampling in this study was conductedbased on certain considerations. According to Ghozali (2008), the strength of the analysis is based on the portion of the model that has the largest number of predictors. Based on these criteria, the number of respondents was determined as 100 .

\section{Result and Discussion}

Respondents'answers to each research variable are tabulatedas the respondents' overall answers to questions regarding tangible, reliability, responsiveness, assurance, empathy, and customer satisfaction. Respondents' answers to the questions on exogenous variables, namely tangible, reliability, responsiveness, assurance and empathy can be seen in Table 1 as follows.

Table 1. Respondents' Answers to Exogenous Variable

\begin{tabular}{|c|c|c|c|c|c|c|c|c|}
\hline \multirow[t]{2}{*}{ Variable } & \multirow[t]{2}{*}{ Question } & \multicolumn{5}{|c|}{ Frequency of Respondents' Answers } & \multirow[t]{2}{*}{ Mean } & \multirow{2}{*}{$\begin{array}{l}\text { Total } \\
\text { Mean }\end{array}$} \\
\hline & & VNS (1) & NS (2) & $\mathrm{N}(3)$ & $\mathrm{S}(4)$ & VS (5) & & \\
\hline \multirow[t]{5}{*}{ Tangible (X1) } & $\mathrm{X} 1.1$ & 0 & 8 & 10 & 44 & 11 & 3,79 & 3,82 \\
\hline & $\mathrm{X} 1.2$ & 0 & 2 & 8 & 49 & 14 & 4,03 & \\
\hline & $\mathrm{X} 1.3$ & 1 & 0 & 12 & 45 & 15 & 4,00 & \\
\hline & $\mathrm{X} 1.4$ & 0 & 2 & 12 & 41 & 18 & 4,03 & \\
\hline & $\mathrm{X} 1.5$ & 4 & 10 & 26 & 29 & 4 & 3,26 & \\
\hline \multirow[t]{3}{*}{ Reliability (X2) } & $\mathrm{X} 2.1$ & 0 & 1 & 6 & 43 & 23 & 4,21 & 4,09 \\
\hline & $\mathrm{X} 2.2$ & 0 & 3 & 7 & 46 & 17 & 4,05 & \\
\hline & $\mathrm{X} 2.3$ & 0 & 2 & 10 & 46 & 15 & 4,01 & \\
\hline \multirow[t]{4}{*}{ Responsiveness (X3) } & X3.1 & 1 & 3 & 10 & 51 & 8 & 3,85 & 3,84 \\
\hline & X3.2 & 0 & 4 & 9 & 51 & 9 & 3,89 & \\
\hline & X3.3 & 0 & 5 & 14 & 43 & 11 & 3,82 & \\
\hline & X3.4 & 0 & 5 & 13 & 46 & 9 & 3,81 & \\
\hline \multirow[t]{4}{*}{ Assurance (X4) } & $\mathrm{X} 4.1$ & 1 & 2 & 5 & 40 & 25 & 4,18 & 4,08 \\
\hline & $\mathrm{X} 4.2$ & 1 & 1 & 8 & 39 & 24 & 4,15 & \\
\hline & $\mathrm{X} 4.3$ & 0 & 1 & 9 & 47 & 16 & 4,07 & \\
\hline & $\mathrm{X} 4.4$ & 1 & 1 & 13 & 46 & 12 & 3,92 & \\
\hline \multirow[t]{3}{*}{ Emphaty(X5) } & X5.1 & 0 & 2 & 6 & 39 & 25 & 4,21 & 4,06 \\
\hline & X5.2 & 1 & 1 & 18 & 42 & 11 & 3,84 & \\
\hline & X5.2 & 0 & 2 & 7 & 42 & 22 & 4,15 & \\
\hline
\end{tabular}

The average for the tangible variable is 3.82 . The reliability variable scored at an average of 4.09. The meanfor responsiveness variable is 3.84. The assurance variable has an average of 4.08. While the mean for empathy variable is 4.06. Respondents' answers to endogenous variables namely customer satisfaction is presented in Table 4.8 as follows.

Table 2. Respondents' Answers to Endogenous Variable

\begin{tabular}{|c|c|c|c|c|c|}
\hline \multirow[t]{2}{*}{ Variable } & \multirow[t]{2}{*}{ Question } & \multicolumn{2}{|c|}{ Frequency of Respondents' Answers } & \multirow{2}{*}{ Mean } & \multirow{2}{*}{$\begin{array}{l}\text { Total } \\
\text { Mean }\end{array}$} \\
\hline & & No (1) & Yes $(2)$ & & \\
\hline \multirow[t]{6}{*}{ Customer Satisfaction (Y) } & Y1 & 16 & 57 & 1,78 & 1,87 \\
\hline & Y2 & 26 & 47 & 1,64 & \\
\hline & Y3 & 4 & 69 & 1,95 & \\
\hline & Y4 & 4 & 69 & 1,95 & \\
\hline & Y5 & 2 & 71 & 1,97 & \\
\hline & Y6 & 5 & 68 & 1,93 & \\
\hline
\end{tabular}


The data collected from Bank Tabungan Negara corporation were analyzed based on internal and external factors; this was then used to determine the company's strategic factors for the SWOT analysis. The external-internal matrix of the position of the BTN Bank,Surabaya Branch Office is as follows.

Table 3. Matrix SWOT Bank Tabungan Negara Corporation (Ltd)

\begin{tabular}{|c|c|c|}
\hline \multirow[b]{2}{*}{ Internal Factor } & Strength $(\mathbf{S})$ & Weaknesses (W) \\
\hline & $\begin{array}{l}\text { 1. S1 Accuracy, security and } \\
\text { trust while in customer } \\
\text { service } \\
\text { 2. } \begin{array}{l}\text { S2 Good physical facilities } \\
\text { during the service period }\end{array}\end{array}$ & $\begin{array}{l}\text { 1. W1 ATM networks that are } \\
\text { easily accessible } \\
\text { 2. W2 } \\
\text { Promotion/Advertisements }\end{array}$ \\
\hline \multicolumn{3}{|l|}{$\begin{array}{l}\text { ExternalFactor } \\
\text { Opnortunities (O) }\end{array}$} \\
\hline $\begin{array}{ll}\text { 1. } & \text { O1 Market } \\
& \text { Share } \\
& \text { area/Dense area } \\
\text { 2. } & \text { O2 Community } \\
& \text { needs for } \\
& \text { banking } \\
\text { transactions }\end{array}$ & $\begin{array}{l}\text { 1. Maintaining quality and } \\
\text { expertise with excellent } \\
\text { service standards for the } \\
\text { wider community as } \\
\text { needed ( } \mathrm{S} 1, \mathrm{~S} 2 ; \mathrm{O} 1, \mathrm{O} 2) \\
\text { 2. Caring for facilities that are } \\
\text { well suited to the } \\
\text { community's need to } \\
\text { conduct banking } \\
\text { transactions }(\mathrm{S} 2, \mathrm{O} 2)\end{array}$ & $\begin{array}{l}\text { 1. Coordinating with ATM } \\
\text { network managers that are } \\
\text { easily accessible for } \\
\text { customers (W1; O1, O2) } \\
\text { 2. Promote or advertise aimed } \\
\text { at a broad market share and } \\
\text { according to community } \\
\text { needs (W2 and O2) }\end{array}$ \\
\hline Threats (T) & Strategy S-T & Strategy W-T \\
\hline $\begin{array}{l}\text { 1. T1 Number of } \\
\text { competing } \\
\text { banks around } \\
\text { BTN KC } \\
\text { Surabaya } \\
\text { 2. T2 Public } \\
\text { purchasing } \\
\text { power }\end{array}$ & $\begin{array}{l}\text { 1. The quality of service and } \\
\text { expertise possessed by } \\
\text { BTN KC Surabaya officers } \\
\text { can be the positioning of } \\
\text { BTN KC Surabaya among } \\
\text { other banks in attracting } \\
\text { public interest (S1, S2, S3; } \\
\text { T1, T2) } \\
\text { 2. Diversifying BTN KC } \\
\text { Surabaya services in } \\
\text { accordance with } \\
\text { community requests (S1, } \\
\text { T1, T2) }\end{array}$ & $\begin{array}{l}\text { 1. Benchmarking competing } \\
\text { banks around BTN KC } \\
\text { Surabaya (W1, W2; T1, } \\
\text { T2) } \\
\text { 2. Make advertising } \\
\text { promotions more attractive } \\
\text { from competing banks and } \\
\text { adjust tariffs with public } \\
\text { purchasing power (W2; T1, } \\
\text { T2) }\end{array}$ \\
\hline
\end{tabular}

Note: $(\mathrm{Si} ; \mathrm{Oi})$ or $(\mathrm{Wi} ; \mathrm{Oi})$ or $(\mathrm{Si} ; \mathrm{Ti})$ or $(\mathrm{Wi} ; \mathrm{Ti})$ shows a combination of external and internal environments in producing strategic options.

\section{Conclusion}

Overall, the results of SWOT integration show that customers are satisfied with the services provided by BTN Surabaya Branch Office. This satisfaction must be compared (benchmarking) with the services provided by competing banks around BTN Surabaya Branch Officeso that services can be improved. The results of this study can be replicated in other units in order to improve the quality of service based on the determined business 
classifications. This is based on the universal nature of research andthus it can be applied to other service industries.

\section{Reference}

[1] Tjiptono, Fandy. 2007. Strategi Pemasaran. Edisi Kedua. Yogyakarta : Andi

[2] LupiyoadidanHamdani, 2006. Manajemen Pemasaran jasa Edisi kedua. Penerbit Salemba Empat: Jakarta.

[3] Hartono, 2008. Analisis Kualitas Pelayanan Terhadap Kepuasan Nasabah PT. Bank Jateng Cabang Purworejo. Surakarta: JurnalDayaSaing, Vol.9, Program MM-UMS.

[4] J. Supranto. 2002. "Pengukuran Tingkat kepuasanPelanggan". Jakarta: Rinekaipta.

[5] Khafafa, Ali. 2013. Customer Satisfaction and Islamic Banking Awareness in the Islamic Banking Window System in Libya. Middle-East Journal of Scientific Research 13.

[6] Umar, Husein. 2005. Riset pemasaran dan Perilaku Konsumen. Jakarta: PT Gramedia Pustaka Utama

[7] Indriantoro, Nur, dan Bambang Supomo, 1999, Metodologi Penelitian dan Bisnis, Yogyakarta: BPFE Yogyakarta.

[8] Masri, Singarimbun.1995. MetodePenelititanSurvei. LP3S, Jakarta

[9] Sugiyono, Prof., Dr., 1999, MetodePenelitianBisnis, Cetakan Ke-6, Bandung,CV. Alfa Beta.

[10] Ghozali, Imam. 2008. Structural Equation Modelling, Edisi II, Universitas Diponegoro, Semarang. 